\title{
IGF-I inhibits apoptosis through the activation of the phosphatidylinositol 3-kinase/Akt pathway in pituitary cells
}

\author{
M Fernández, F Sánchez-Franco'1, N Palacios, I Sánchez, C Fernández ${ }^{1}$ and \\ L Cacicedo \\ Servicio de Endocrinología, Hospital Ramón y Cajal, Carretera de Colmenar, Km 9, 28034 Madrid, Spain, ${ }^{1}$ Servicio de Endocrinología, Hospital \\ Carlos III-CIC, Instituto de Salud Carlos III, Sinesio Delgado, 10-12, 28029 Madrid, Spain
}

(Requests for offprints should be addressed to L Cacicedo; E-mail: Icacicedo@ hotmail.com)

\begin{abstract}
In previous studies we demonstrated that IGF-I induces proliferation of pituitary lactotrophs. In addition to its mitotrophic actions, IGF-I is known to prevent apoptosis induced by diverse stimuli in several cell types. In this study, we investigated the action of IGF-I on pituitary cell survival and the intracellular signaling transduction pathway implicated in this effect. Treatment of cultured male rat pituitary cells with IGF-I $\left(10^{-7} \mathrm{M}\right)$ for $24 \mathrm{~h}$ prevented pituitary cell death induced by serum deprivation. The protective effect of IGF-I was blocked by phosphoinositide 3-kinase (PI3-kinase) inhibitor, LY294002, but was unaffected by PD98059, which inhibits MAP/ERK kinase (MEK1). IGF-I activation of PI3-kinase induced the phosphorylation and activation of the serine/threonine kinase Akt. Moreover, IGF-I increased the phosphorylation of the pro-apoptotic factor Bad and the levels of the anti-apoptotic protein $\mathrm{Bcl}-2$ through the PI3-kinase pathway in primary pituitary cells.
\end{abstract}

Journal of Molecular Endocrinology (2004) 33, 155-163

\section{Introduction}

Insulin-like growth factor-I (IGF-I) is known to support growth and to prevent apoptosis in many cell types (LeRoith et al. 1995). The positive effect of IGF-I on cell survival has been described in several systems, using various apoptotic stimuli (Butt et al. 1999).

The actions of IGF-I are mediated through a tyrosine kinase receptor that leads to the activation of phosphoinositide 3-kinase (PI3-kinase) and the mitogen-activated protein kinase (MAPK) (LeRoith et al. 1995). Several studies have demonstrated that IGF-I induces cell survival via activation of the PI3-kinase pathway (Párrizas et al. 1997, Gagnon et al. 2001). Akt, a target of PI3-kinase, partially inhibits apoptosis (Kulik et al. 1997) by phosphorylating and inactivating the pro-apoptotic Bcl-2 member, Bad, at Ser136, blocking the Bad-induced death (Datta et al. 1997, 1999). Phosphorylated Bad is sequestered by 14-3-3 protein, leading to its down-regulation. In addition, the PI3-kinase/Akt pathway also increases the levels of anti-apoptotic proteins including Bcl-2 and Bcl-xL (Chrysis et al. 2001). The protective effect of IGF-I in PG12 cells has been associated both with an increase of $\mathrm{Bcl}-\mathrm{xL}$ mRNA and protein levels (Párrizas \& LeRoith 1997), and with the activation of $\mathrm{Bcl}-2$ expression at the transcriptional level (Pugazhenthi et al. 2000). Alternate IGF-Idependent survival signaling pathways, including the Ras/MAPK cascade and p38 MAPK, have also been proposed (Párrizas et al. 1997, Kulik \& Weber 1998). However, current data suggest that IGF-I-mediated MAPK-dependent survival may predominate only when the PI3-kinase pathway is damaged (Peruzzi et al. 1999).

IGF-I has been implicated in the regulation of pituitary hormones synthesis and release (Yamashita \& Melmed 1986, Lara et al. 1994). In mice with disrupted IGF-I gene, structural and functional alterations occur in somatotrophs and lactotrophs (Stefaneanu et al. 1999). Pituitary secretory cells, which play a key role in hormone 
homeostasis, require trophic support for survival in culture. In previous studies we demonstrated that IGF-I stimulates proliferation of cultured rat pituitary lactotroph cells via activation of the MAPK pathway (Fernández et al. 2003). While the effectiveness of IGF-I on inhibition of apoptosis in many cell types (LeRoith et al. 1995) is well established, the effect of IGF-I on primary pituitary cell survival, the signaling pathways leading to apoptosis, and the mechanisms of action by which IGF-I and other agents prevent apoptosis are largely unknown.

Therefore, the aim of this study was to determine whether IGF-I is capable of protecting primary pituitary cells from apoptosis induced by serum deprivation, which is an established model for analyzing apoptotic pathways (Kennedy et al. 1997), and to investigate the mechanisms activated by IGF-I and their role in pituitary cell survival. We have studied the implication of the PI3-kinase/Akt pathway in the protective effect of IGF-I and whether IGF-I may induce Bad phosphorylation. The contribution of the IGF-I-induced PI3-kinase/ Akt pathway in increasing the levels of the anti-apoptotic protein Bcl-2 was also examined.

\section{Materials and methods}

\section{Reagents}

Recombinant human IGF-I (rhIGF-I) was purchased from PreproTech EG (London, UK). All antibodies were purchased from Dako (Glostrup, Denmark) unless otherwise specified. Poly-Lornithine was purchased from Sigma (St Louis, MO, USA). The chemical inhibitors PD98059 and LY294002 were obtained from Alexis Corp. (San Diego, CA, USA).

\section{Buffers and media}

Dulbecco's modified Eagle's medium (DMEM), fetal calf serum (FCS), Hank's balanced salt solution (HBSS), phosphate-buffered saline (PBS), penicillin-streptomycin, and L-glutamine were purchased from Bio Whittaker (Walkersville, MD, USA).

Defined medium consisted of DMEM (glucose $1 \mathrm{~g} / \mathrm{l})$ supplemented with: BSA $1 \%$, Hepes $(15 \mathrm{mM}), \quad$ hydrocortisone $\quad(0 \cdot 1 \mu \mathrm{M}), \quad$ triiodothyronine $\left(\mathrm{T}_{3} ; 0.5 \mathrm{nM}\right)$, transferrin $(10 \mu \mathrm{M})$, glucagon $(10 \mathrm{nM})$ and parathyroid hormone $(\mathrm{PTH}$; $0.2 \mathrm{nM})$ from Sigma, L-glutamine $(4 \mathrm{mM})$ and penicillin-streptomycin $(100 \mathrm{U} / \mathrm{ml})$.

\section{Cell culture}

Preparation of primary rat anterior pituitary cell cultures was carried out as previously described (Cacicedo \& Sánchez-Franco 1986). Two-monthold male Sprague-Dawley rats were supplied by Charles River (Barcelona, Spain). Animal handling was conducted in accordance with the guidelines on protection of animals used in scientific research set by Real Decreto 223/1988 14 March and Orden 13 October 1989. The animals were killed by decapitation and their pituitary glands were removed under sterile conditions. The neurohypophyses were discarded and the anterior pituitaries collected and mechanico-enzymatically dispersed with $0 \cdot 1 \%$ papain, $0 \cdot 1 \%$ neutral protease and $0 \cdot 1 \%$ DNase for $1 \mathrm{~h}$ at $37^{\circ} \mathrm{C}$. The dispersed pituitary cells were re-suspended in defined medium containing FCS (3\%) and were plated on poly-L-ornithine-coated $35 \mathrm{~mm}$ tissue culture dishes and seeded at a density of $5 \times 10^{5}$ cells per dish. Cultures were kept in a humidified atmosphere of $5 \% \mathrm{CO}_{2}: 95 \%$ air at $37^{\circ} \mathrm{C}$.

For cell survival studies, cultures were kept for $72 \mathrm{~h}$ in serum-supplemented defined medium. Then a group of plates $(t=0)$ were removed and cells counted in duplicate using a Neubauer chamber. Another group of plates was cultured in serum free medium (control) or IGF-I $\left(10^{-7} \mathrm{M}\right.$ ) alone or in the presence of the PI3-kinase inhibitor, LY294002 $(20 \mu \mathrm{M})$, or the MAP/ERK kinase inhibitor, PD98059 $(10 \mu \mathrm{M})$. After $24 \mathrm{~h}$ cells were counted and cell viability was assessed by the trypan blue dye exclusion. Results are expressed as the percentage of viable adherent cells relative to serum-fed controls $(t=0)$.

\section{Cell death assessment}

Cell death detection assay was undertaken according to the manufacturer's instructions (Roche Applied Science, Barcelona, Spain). Fluorescein-16-deoxy-UTP was used and TUNEL signal was visualized with a fluorescent microscope (Nikon, Eclipse 400, Madrid, Spain). Anterior pituitary cells were plated on poly-L-ornithinecoated glass coverslips in 24-well culture plates and 
incubated as described above. Cultures were kept for $72 \mathrm{~h}$ in serum supplemented medium. Thereafter a group of coverslips $(n=4)(t=0)$ was removed and cells were fixed. Another group of cells was cultured in serum-free medium $(n=20)$ or IGF-I $\left(10^{-7} \mathrm{M}\right)(n=20)$. After 3, 6, $12(t=12), 18$ and $24 \mathrm{~h}$ cells (eight coverslips/experimental time period) were fixed, cell death was assessed by TUNEL. Nuclei were counterstained with 4-6-Diamidino-2phenyindole, dilactate (DAPI). The number of TUNEL-positive cells per coverslip was scored by counting all TUNEL-positive cells in every coverslip. Results express the percentage of TUNEL over DAPI-positive nuclei relative to serum-fed controls $(t=0)$.

\section{Experimental design}

Signaling pathway studies were determined in anterior pituitary cells by quantitation of phosphorylated forms of Akt (Ser473) and Bad (Ser136). Pituitary cells were plated on poly-L-ornithinecoated $35 \mathrm{~mm}$ tissue culture dishes as described above. After $72 \mathrm{~h}$ of incubation in serumsupplemented medium, cells were cultured in defined medium (serum free) for $24 \mathrm{~h}$. Then, the medium was replaced by defined medium containing IGF-I $\left(10^{-7} \mathrm{M}\right)$ for the times indicated in the figures. The levels of phosphorylated Akt and Bad were quantitated by Western immunoblotting as described below.

The anti-apoptotic action of IGF-I was determined by quantitation of Bcl-2. Pituitary cells were incubated as described above, and cells were then exposed to defined medium containing IGF-I $\left(10^{-7} \mathrm{M}\right)$ for 24 or $48 \mathrm{~h}$. Bcl-2 protein levels were determined by Western immunoblotting as described below.

To determine the signaling pathways involved in the action of IGF-I on Akt activation and the levels of the anti-apoptotic protein Bcl-2, cells were pretreated with the PI3-kinase inhibitor, LY294002 $(20 \mu \mathrm{M})$ for $45 \mathrm{~min}$ prior to the addition of IGF-I. Cells were then incubated for the times indicated in the figures. LY294002 was dissolved with methanol at a concentration of $3.2 \mathrm{mM}$ and was diluted immediately before use.

\section{Western immunoblots}

Anterior pituitary cells, growing in $35 \mathrm{~mm}$ dishes, were lysed in a buffer containing $0.1 \mathrm{M} \mathrm{NaCl}$,
0.01 M Tris-HCl pH 7·6, 0.001 M EDTA, 0.1\% NP-40, $1 \mu \mathrm{g} / \mathrm{ml}$ aprotinin and $100 \mu \mathrm{g} / \mathrm{ml}$ phenylmethylsulfonyl fluoride (PMSF). Equal amounts of protein extracts $(40 \mu \mathrm{g})$ from pools of three samples were resolved by SDS-PAGE and transferred to a PVDF membrane. After blocking the membranes, immunodetection was performed using antibodies that recognize phosphorylated forms of Akt (Ser473) (1:350 dilution, New England Biolabs, Ozyme, France) and Bad (Ser 136) (1:500 dilution, Cell Signaling Technology, Beverly, MA, USA), and Bcl-2 antibody (1:10 000 dilution, St Cruz Biotechnology, CA, USA), followed by incubation with a goat peroxidase-conjugated anti-mouse or anti-rabbit secondary antibodies (Dako). Membranes were re-probed with phosphorylation state-independent antibodies, Akt (New England Biolabs) and Bad (Cell Signaling Technology). For Bcl-2, the membranes were systematically treated with Coomassie brilliant blue R-250 solution $(0 \cdot 125 \%)$, as a loading control.

\section{Statistical analysis}

Statistical analysis was performed using pooled data from three independent experiments. Triplicate wells were tested within each experiment. All data are expressed as the means \pm s.E. Tests for significance between sample groups were performed with a two-tailed $t$-test. For multiple comparisons, ANOVA was used with the Fisher test for post hoc comparisons. Differences were considered statistically significant if $P<0 \cdot 05$.

\section{Results}

\section{IGF-I reverses apoptosis in pituitary cells through activation of the PI3-kinase pathway}

The ability of IGF-I to protect pituitary cells from apoptosis was studied by incubating the cells in starvation medium with IGF-I. Pituitary cells placed in starvation medium for $24 \mathrm{~h}$ reduced by $41 \%$ the number of viable cells $(t=0,100 \%$; $t=24 \mathrm{~h}, 59 \pm 7 \cdot 8 \%)(P<0 \cdot 05)$. Addition of IGF-I $\left(10^{-7} \mathrm{M}\right)$ to the starvation medium for $24 \mathrm{~h}$ prevented cell death $(t=24 \mathrm{~h}, 101 \pm 3 \%)$ (Fig. 1). TUNEL labeling was increased in rat pituitary cells placed in starvation medium for 12, 18 and $24 \mathrm{~h}$. A maximum effect was observed at $12 \mathrm{~h}(t=0,100 \%$; $t=12,281 \cdot 05 \pm 3 \cdot 75 \%, P<0 \cdot 01)$. The addition of 


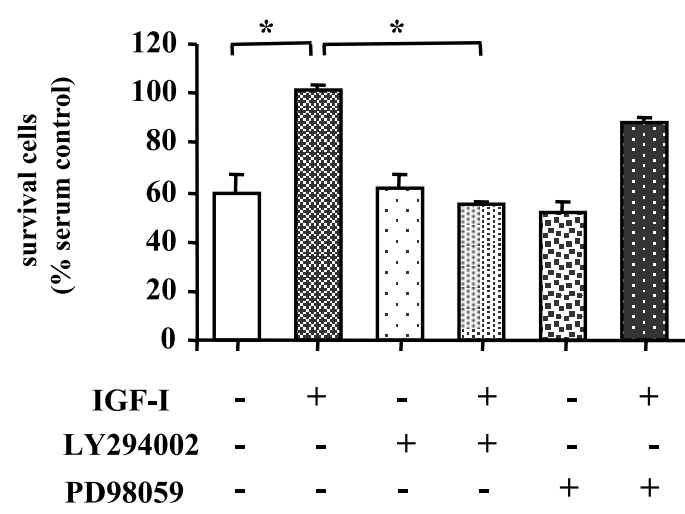

Figure 1 IGF-I protects pituitary cells from serum withdrawal-induced apoptosis through the activation of PI3-kinase pathway. After $72 \mathrm{~h}$ in serum-supplemented defined medium $(t=0)$, pituitary cells were placed in starvation medium in the absence (control) or presence of IGF-I (10-7 M), in combination with LY294002 $(20 \mu \mathrm{M})$ or PD98059 $(10 \mu \mathrm{M})$. After $24 \mathrm{~h}$ of treatment, cells were counted in duplicate. Results are expressed as the percentage of viable cells relative to serum-fed controls $(t=0)$. Values represent means \pm S.E. of two independent experiments $(n=2)$. ${ }^{*} P<0.05$.

IGF-I $\left(10^{-7} \mathrm{M}\right)$ to the starvation medium rescued rat pituitary cells from apoptosis $(t=0,100 \%$; IGF-I 12 h, $69 \cdot 66 \pm 14 \cdot 91 \%$, NS). Pituitary cells cultured in starvation medium showed a high proportion of nuclei of small size, round in shape and stained brightly with DAPI (data not shown). This dose of IGF-I was shown to be optimal for the proliferation of pituitary cells (Fernández et al. 2003). These data indicate that IGF-I is a survival factor for primary pituitary cells.

PI3-kinase and MAPK have been proven to be involved in the IGF-I anti-apoptotic effect in PG12 (Butt et al. 1999). To identify whether these signals are important for the protective action of IGF-I in pituitary cells, cells were incubated in starvation medium for $24 \mathrm{~h}$, in the presence or absence of IGF-I in combination with a variety of specific inhibitors. The anti-apoptotic properties of IGF-I were completely blocked after addition of $20 \mu \mathrm{M}$ LY294002, an inhibitor of PI3-kinase $(t=24 \mathrm{~h}$, $55 \pm 1 \cdot 2 \%)(P<0.05$ compared with IGF-I treatment alone). However, $10 \mu \mathrm{M}$ PD98059, an inhibitor of MEK1, had no significant effect on IGF-I-dependent survival in pituitary cells $(t=24 \mathrm{~h}$, $88 \pm 2 \cdot 1 \%)$. These inhibitors alone, in the absence of IGF-I, had no significant effect on the survival of pituitary cells.
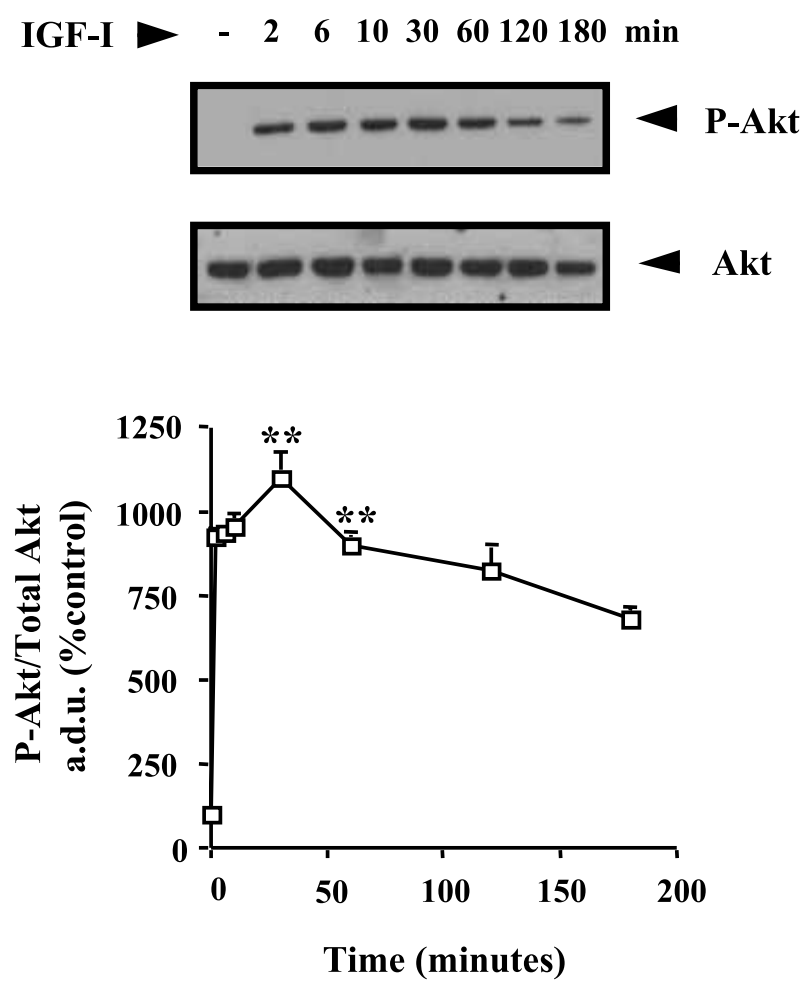

Figure 2 Time course of IGF-I-induced Akt phosphorylation. Anterior pituitary cells were treated with IGF-I $\left(10^{-7} \mathrm{M}\right)$ for the times indicated. The upper panel shows a representative immunoblot using antibodies against total and phospho-Ser473 Akt (P-Akt). The lower panel shows the densitometric values (arbitrary densitometric units, a.d.u.) gathered from three independent experiments. Values represent means \pm S.E. $(n=3) .{ }^{* *} P<0.01$ vs $t=0$.

\section{IGF-I stimulates Akt activation in pituitary cells}

Akt has been shown to participate in growth factor-induced cell survival against several apoptotic stimuli (Kulik et al. 1997). To investigate the role of IGF-I on Akt activation, dissociated rat anterior pituitary cells were incubated with IGF-I $\left(10^{-7} \mathrm{M}\right)$ for varying times. The levels of phosphorylated Akt were examined using an antibody that recognizes phospho-Ser473 Akt. Treatment of pituitary cells with IGF-I resulted in the rapid and sustained phosphorylation of Akt, which is indicative of its activity. Maximal phosphorylation (tenfold) was observed at $2 \mathrm{~min}$ and maintained for $60 \mathrm{~min}$ after IGF-I treatment. Phosphorylation remained elevated for $180 \mathrm{~min}$ $(P<0 \cdot 01)$ (Fig. 2). To determine whether the effect of IGF-I on Akt phosphorylation involved the 

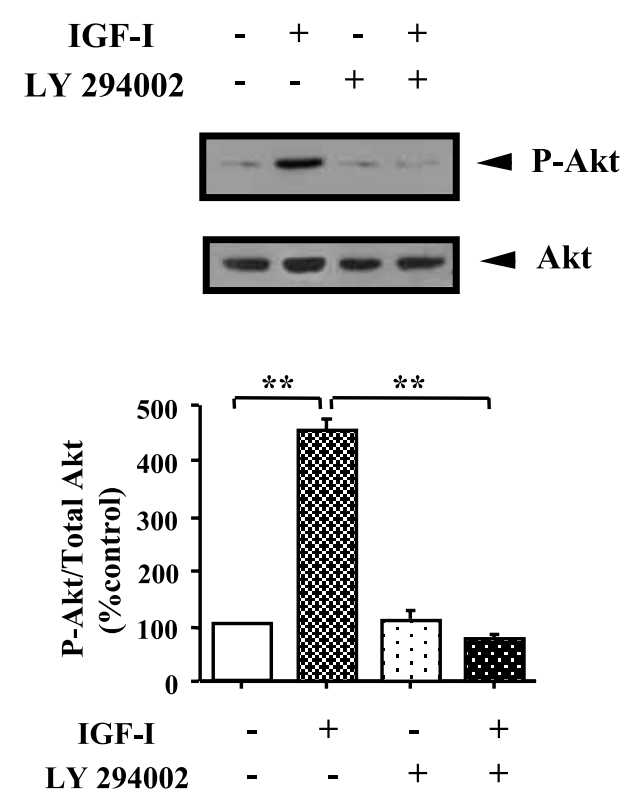

Figure 3 Effect of PI3-kinase inhibitor on IGF-I-induced Akt phosphorylation. Anterior pituitary cells were pretreated with LY294002 $(20 \mu \mathrm{M})$ and then incubated in the presence or absence of IGF-I (10-7 M) for $2 \mathrm{~min}$. The upper panel shows a representative immunoblot using antibodies against phospho-Ser473 (P-Akt) and total Akt. The lower panel shows the relative densitometric values (a.d.u.) of P-Akt gathered from three independent experiments. Values represent means \pm S.E. $(n=3) .{ }^{* \star} P<0.01$.

PI3-kinase, cells were pretreated with the PI3kinase inhibitor, LY294002 $(20 \mu \mathrm{M})$. As shown in Fig. 3, the effect of IGF-I on Akt activation was completely abolished $(P<0 \cdot 01)$ by LY294002. These results indicate that IGF-I induces Akt phosphorylation via activation of the PI3-kinase signaling pathway.

\section{IGF-I phosphorylates Bad in pituitary cells}

Extracellular factors may promote cell survival by stimulating the phosphorylation of $\mathrm{Bad}$, which reduces Bad-Bcl-2 heterodimer formation and thereby potentiates the effects of anti-apoptotic mediators such as Bcl-2. To investigate the role of IGF-I on Bad phosphorylation, rat anterior pituitary cells were incubated with IGF-I $\left(10^{-7} \mathrm{M}\right)$ for varying times. The levels of phosphorylated Bad were examined using an antibody that recognizes phospho-Ser136 Bad. As shown in Fig. 4, treatment with IGF-I resulted in the rapid and transient phosphorylation of Bad. Maximum levels
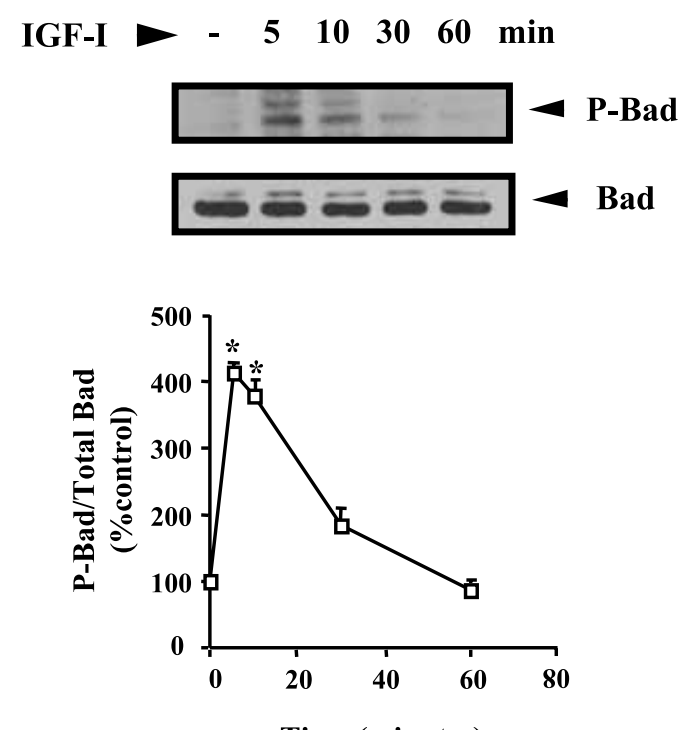

Time (minutes)

Figure 4 Time course of IGF-I-induced Bad phosphorylation. Anterior pituitary cells were treated with IGF-I $\left(10^{-7} \mathrm{M}\right)$ for the times indicated. The upper panel shows a representative immunoblot using antibodies against phospho-Ser136 Bad (P-Bad) and total Bad. The lower panel shows the relative densitometric values (a.d.u.) of P-Bad gathered from three independent experiments. Values represent means \pm S.E. $(n=2)$. ${ }^{\star} P<0.05$ vs $t=0$.

(fourfold) were observed at 5 and $10 \mathrm{~min}$ after IGF-I treatment, declining to basal levels at $60 \mathrm{~min}$. These results suggest that IGF-I induces Ser136 phosphorylation of Bad in primary pituitary cells.

\section{IGF-I increases the anti-apoptotic protein Bcl-2 via the PI3-kinase pathway in primary pituitary cells}

Up-regulation of Bcl-2 expression has been identified as a critical mechanism by which growth factors promote cell survival (Singleton et al. 1996, Pugazhenthi et al. 2000). The ability of IGF-I to induce Bcl-2 protein levels was studied by incubating the pituitary cells with varying concentrations of IGF-I. IGF-I was effective in inducing Bcl-2 protein in both a time- and a dose-dependent fashion. The effect of IGF-I was detected at $24 \mathrm{~h}$ and at a concentration of $10^{-7} \mathrm{M}$, with maximal effects seen at $48 \mathrm{~h}$. Lower concentrations of IGF-I $\left(10^{-8} \mathrm{M}\right)$ were not effective in inducing $\mathrm{Bcl}-2$ protein (Fig. 5). To determine whether the effect of IGF-I on the induction of Bcl-2 in pituitary cells 


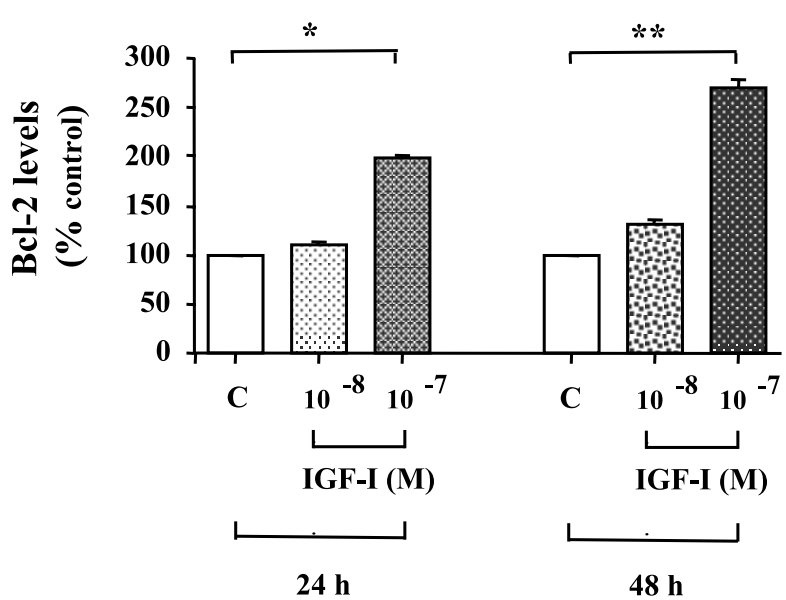

Figure 5 Effect of IGF-I on Bcl-2 protein levels in anterior pituitary cells: dose-response and time course. Anterior pituitary cells were treated with IGF-I $\left(10^{-7}\right.$ and $10^{-8} \mathrm{M}$ ) for the times indicated. The densitometric values (a.d.u.) gathered from three independent experiments are shown. Values represent means \pm S.E. $(n=3) .{ }^{\star} P<0.05$ vs control $(C) ;{ }^{* *} P<0.01$ vs control.

involved the PI3-kinase pathway, cells were pretreated for $45 \mathrm{~min}$ with LY294002 $(20 \mu \mathrm{M})$. As shown in Fig. 6, the effect of IGF-I $\left(10^{-7} \mathrm{M}\right)$ on
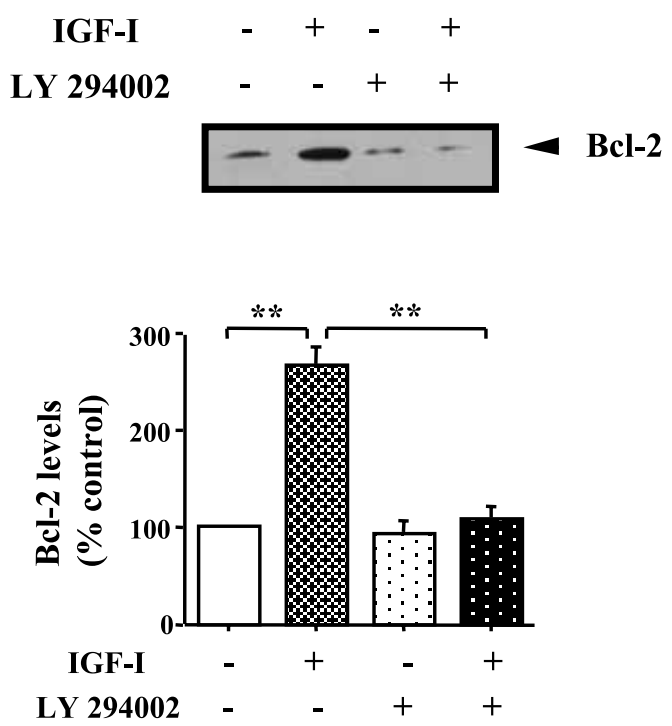

Figure 6 PI3-kinase mediates IGF-I-induced Bcl-2 protein levels. Anterior pituitary cells were pretreated with LY294002 $(20 \mu \mathrm{M})$ and then incubated in the presence or absence of IGF-I ( $\left.10^{-7} \mathrm{M}\right)$ for $48 \mathrm{~h}$. The upper panel shows a representative immunoblot of $\mathrm{Bcl}-2$. The lower panel shows the relative densitometric values (a.d.u.) of $\mathrm{Bcl}-2$ gathered from three independent experiments. Values represent means \pm S.E. $(n=3)$. ${ }^{* *} P<0.01$.
Bcl-2 expression was completely abolished by the PI3-kinase inhibitor $(P<0 \cdot 01)$. These results support the conclusion that IGF-I induces Bcl-2 protein levels and that the PI3-kinase/Akt pathway plays a role in mediating this effect.

\section{Discussion}

We have identified IGF-I as a survival factor for primary pituitary cells and characterized its intracellular signaling targets. IGF-I protects pituitary cells from apoptosis, induced by serum deprivation, by a mechanism dependent on the activation of PI3-kinase. Furthermore, we show that IGF-I induces the phosphorylation of the pro-apoptotic factor $\mathrm{Bad}$, and increases the levels of the anti-apoptotic protein Bcl-2 via the PI3-kinase/ Akt signaling pathway.

We found that IGF-I prevented the loss of pituitary cells induced by serum withdrawal. This could reflect actions of IGF-I on cell proliferation as we have previously demonstrated that IGF-I induces proliferation of pituitary cells (Fernández et al. 2003). However the proliferative action of IGF-I was effective as from $48 \mathrm{~h}$, but was not evident at $24 \mathrm{~h}$, the time at which the survival effects of IGF-I were observed. Furthermore, the TUNEL assay confirmed that the addition of IGF-I to the starvation medium rescued rat pituitary cells from apoptosis. Thus the present results support the conclusion that IGF-I promotes survival of primary pituitary cells and confirm recent evidence which has demonstrated that the signaling through the IGF-I system plays a powerful role in cell survival and prevention of programmed cell death in various cell types (LeRoith et al. 1995). The identity of the cell types within the pituitary that IGF-I protects from apoptosis, induced by serum deprivation, is not entirely clear. IGF-I receptor mRNA is abundantly and homogeneously distributed throughout the anterior pituitary and intermediate lobes (Bach \& Bondy 1992). Immunocytochemically, IGF-I receptors have been shown to be present in gonadotrophs (Unger \& Lange 1997), corticotrophs and somatotrophs (Takahashi et al. 1997). The anti-apoptotic actions of IGF-I on pituitary cells have been previously reported using primary tilapia pituitary cell cultures (Melamed et al. 1999). A very recent report (Arroba et al. 2003) demonstrates that lactotrophs were TUNEL 
labeled in pituitaries of diabetic rats which have low insulin and peripheral IGF-I. Our data suggest the possibility that survival of various cell types, including lactotrophs, may be regulated by IGF-I.

Survival signaling through the IGF-I receptor is dependent on the kinase activity of the receptor. PI3-kinase is a major effector for signaling by IGF-I receptor. We have demonstrated that the activation of the PI3-kinase/Akt pathway seems to be required for IGF-I-dependent pituitary cell survival. We found that the ability of IGF-I to protect cells from apoptosis was fully blocked by LY294002. Thus activation of PI3-kinase is necessary for protecting primary pituitary cells from apoptosis. The involvement of the MAPK pathway in the IGF-I dependent pituitary cell survival was tested using PD98059 and we found that MAPK signaling was not required for IGF-I-dependent pituitary cell survival. This pathway of IGF-I signaling has been closely related with cell differentiation, migration and proliferation (Fernández et al. 2003), but in some cases it can also regulate the machinery of apoptosis (Párrizas et al. 1997).

We considered the possibility that the effects of IGF-I on cell survival were mediated by the protein kinase Akt, a downstream effector for PI3-kinase, that is activated by a number of growth factors, including insulin, through a PI3-kinase-dependent mechanism (Cross et al. 1995). Our results indicate that IGF-I induces a rapid and sustained stimulation of the Akt phosphorylation, suggesting that Akt may play a critical role in promoting IGF-I-dependent survival in primary pituitary cells. As previously shown (Yao \& Cooper 1995), we confirmed that activation of Akt is blocked by the PI3-kinase inhibitor LY294002, which indicates that this activation is dependent on PI3-kinase.

The mechanism by which PI3-kinase/Akt offers cytoprotection remains unclear. Several factors involved in apoptosis and cellular survival have been shown to be regulated by Akt (Kennedy et al. 1997, Datta et al. 1999). Thus Akt may use a variety of pathways to promote cell survival (Datta et al. 1997, Khwaja 1999). One mechanism by which Akt may promote survival is through the inhibition of components of the cell death pathway. Our results indicate for the first time that IGF-I induces a transient phosphorylation and inactivation of the pro-apoptotic Bcl-2 family member, Bad, in primary pituitary cells. Previous studies have demonstrated that IGF-I leads to Bad phosphorylation at Ser136 and blocks the Bad-induced death through the PI3-kinase/Akt signaling pathway in several cell types (Vincent \& Feldman 2002). It has been proposed that phosphorylation of Bad may lead to the prevention of cell death via a mechanism that involves the selective association of the phosphorylated forms of Bad with 14-3-3 proteins (Zha et al. 1996). The induced association of $\mathrm{Bad}$ with 14-3-3 appears to prevent $\mathrm{Bad}$ association with Bcl-xL or Bcl-2 (Datta et al. 1997). The transient rise in Bad has been described by other authors using human SH-SY5Y cells exposed to methylpyridinium (MPP) (Halvorsen et al. 2002). The significant reduction in Bad phosphorylation by $30 \mathrm{~min}$ observed in the present study cannot be accounted for by reduction in activating phosphorylation of Akt. This paradox suggested the possibility of the appearance of phosphatases capable of dephosphorylating and inactivating Bad (Keyse 2000).

However, these results do not rule out the possibility that Akt promotes cell survival by other mechanisms in addition to that mediated by phosphorylation of Bad. Recent studies also implicate Akt upstream of caspase activation in the apoptosis cascade, regulating mitochondrial membrane integrity and cytochrome c release, independently of Bad phosphorylation (Kennedy et al. 1999). In addition, the activity of Akt also increases the levels of anti-apoptotic proteins including Bcl-2 (Chrysis et al. 2001). Our results indicate that IGF-I increased the levels of $\mathrm{Bcl}-2$ in primary pituitary cells. This finding is in agreement with previous studies, which have demonstrated that IGF-I was able to elevate Bcl-xL mRNA and protein levels in PC12 cells (Párrizas \& LeRoith 1997). Bcl-2 is well known as an important factor promoting cell survival in several cell preparations (Reed 1997). Bcl-2 and other anti-apoptotic members of this family such as Bcl-xL partially suppress apoptosis by blocking the release of apoptogenic molecules from mitochondria such as cytochrome c.

Up-regulation of $\mathrm{Bcl}-2$ expression has been identified as a critical mechanism by which growth factors promote cell survival (Singleton et al. 1996, Pugazhenthi et al. 1999). Our results do not show a direct link between the protective effect of IGF-I and its up-regulation of Bcl-2. However previous data showing that $\mathrm{Bcl}-2$ overexpression can protect serum-deprived PG12 cells (Batistatou et al. 1993) 
argues for a role of $\mathrm{Bcl}-2$ in the IGF-I-induced survival of primary pituitary cells. The present study also examined whether IGF-I-induced Bcl-2 protein levels occur through the PI3-kinase/Akt pathway. The data shown indicate that IGF-I increased $\mathrm{Bcl}-2$ protein levels via the PI3-kinase/ Akt signaling pathway. Previous studies reported that IGF-I-induced Bcl-2 expression involves a signaling cascade mediated by PI3-kinase/PDK1/ Akt in PG12 cells (Pugazhenthi et al. 2000).

In summary, we have demonstrated that the PI3-kinase/Akt pathway is required for IGF-Iregulated pituitary cell survival. The inactivation of $\mathrm{Bad}$ and the increase of $\mathrm{Bcl}-2$ protein levels suggests that these proteins may be involved in IGF-I-induced pituitary cell survival in a PI3-kinase-dependent manner.

\section{Acknowledgements}

We thanks Constanza Navarro for technical assistance, Mary Harper for the preparation of the manuscript and Dr J. Jordan for a critical reading of the manuscript. This work was supported by grants SAF-2001-0016 from the Ministerio de Ciencia y Tecnología, and FIS 01/0127 and P1020720 from the Fondo de Investigaciones

Sanitarias.

\section{References}

Arroba AI, Frago LM, Pañeda C, Argente J \& Chowen JA 2003 The number of lactotrophs is reduced in the anterior pituitary of streptozotocin-induced diabetic rats. Diabetologia $46634-638$.

Bach MA \& Bondy CA 1992 Anatomy of the pituitary insulin-like growth factor system. Endocrinology 131 2588-2594.

Batistatou A, Merry DE, Korsmeyer SJ \& Green LA 1993 Bcl-2 affects survival but not neuronal differentiation of PC12 cells. Foumal of Neuroscience 13 4422-4428.

Butt AJ, Firth SM \& Baxter RC 1999 The IGF axis and programmed cell death. Immunology and Cell Biology 77 256-262.

Cacicedo L \& Sánchez-Franco F 1986 Direct action of opioid peptides and naloxone on gonadotropin secretion by cultured rat anterior pituitary cells. Life Sciences 38 617-625.

Chrysis D, Calikoglu AS, Ye P \& D'Ercole AJ 2001 Insulin-like growth factor-I overexpression of $\mathrm{Bcl}$ family proteins in a developmentally specific manner. Fournal of Neuroscience $\mathbf{2 1}$ 1481-1489.

Cross DAE, Alessi DR, Cohen P, Andjelkovic M \& Hemmings BA 1995 Inhibition of glycogen synthase kinase-3 by insulin mediated by protein kinase B. Nature $\mathbf{3 7 8} 785-789$.

Datta SR, Dudek H, Tao X, Masters S, Fu H, Gotoh Y \& Greenberg ME 1997 Akt phosphorylation of BAD couples survival signals to the cell-intrinsic death machinery. Cell $\mathbf{9 1}$ 231-241
Datta SR, Brunet A \& Greenberg ME 1999 Cellular survival: a play in three Akts. Genes and Development 13 2905-2927.

Fernández M, Sánchez-Franco F, Palacios N, Sánchez I, Villuendas G \& Cacicedo L 2003 Involvement of VIP on IGF-I-induced proliferation of rat lactotrophs in pituitary culture: evidence for an autocrine and/or paracrine regulatory system. Neuroendocrinology $\mathbf{7 7}$ 341-352.

Gagnon A, Dods P, Roustan-Delatour N, Chen C \& Sorisky A 2001 Phosphatidylinositol-3,4,5-trisphosphate is required for insulin-like growth factor 1-mediated survival of 3T3-L1 preadipocytes. Endocrinology 142 205-212.

Halvorsen EM, Dennis J, Keeney P, Sturgill TW, Tuttle JB \& Bennett JB Jr 2002 Methylpyridinium $(\mathrm{MPP}(+))$ - and nerve growth factor-induced changes in pro- and anti-apoptotic signaling pathways in SH-SY5Y neuroblastoma cells. Brain 952 98-110.

Kennedy SG, Wagner AJ, Conzen SD, Jordan J, Bellacosa A, Tsichlis PN \& Hay N 1997 The PI3-kinase/Akt signaling pathway delivers an anti-apoptotic signal. Genes and Development 11 701-713.

Kennedy SG, Kandel ES, Cross TK \& Hay N 1999 Akt/Protein kinase $\mathrm{B}$ inhibits cell death by preventing the release of cytochrome c from mitochondria. Molecular and Cellular Biology 19 $5800-5810$

Keyse SM 2000 Protein phosphatases and the regulation of mitogen-activated protein kinase signaling. Current Opinion in Cell Biology 12 186-192.

Khwaja A 1999 Akt is more than just a Bad kinase. Nature 401 33-34.

Kulik G \& Weber MJ 1998 Akt-dependent and -independent survival signaling pathways utilized by insulin-like growth factor I. Molecular and Cellular Biology 18 6711-6718.

Kulik G, Klippel A \& Weber MJ 1997 Antiapoptotic signalling by the insulin-like growth factor I receptor, phosphatidylinositol 3-kinase, and Akt. Molecular and Cellular Biology 17 1595-1606.

Lara JI, Lorenzo MJ, Tolón RM, Balsa JA, Cacicedo L, López-Fernández J \& Sánchez-Franco F 1994 Induction of vasoactive intestinal peptide gene expression and prolactin secretion by insulin-like growth factor in rat pituitary cells: evidence for an autoparacrine regulatory system. Endocrinology 135 $2526-2532$

LeRoith D, Werner H, Beitner-Johnson D \& Roberts CT 1995 Molecular and cellular aspects of insulin-like growth factor I receptor. Endocrine Reviews 16 143-163.

Melamed P, Gur G, Rosenfeld H, Elizur A \& Yaron Z 1999 Possible interactions between gonadotrophs and somatotrophs in the pituitary of tilapia: apparent roles for insulin-like growth factor I and estradiol. Endocrinology 140 1183-1191.

Párrizas M \& LeRoith D 1997 Insulin-like growth factor-I inhibition of apoptosis is associated with increased expression of the bcl-xL gene product. Endocrinology 138 1355-1358.

Párrizas M, Saltiel AR \& LeRoith D 1997 Insulin-like growth factor I inhibits apoptosis using the phosphatidylinositol 3'-kinase and mitogen-activated protein kinase pathways. Fournal of Biological Chemistry 272 154-161.

Peruzzi F, Prisco M, Dews M, Salomoni P, Grassilli E, Romano G, Calabretta B \& Baserga R 1999 Multiple signaling pathways of insulin-like growth factor 1 receptor in protection from apoptosis. Molecular and Cellular Biology 19 7203-7215.

Pugazhenthi S, Millere E, Sable C, Young P, Heidenreich KA, Boxer LM \& Reusch JEB 1999 Insulin-like growth factor-I induces bcl-2 promoter through the transcription factor cAMP-response element-binding protein. Fournal of Biological Chemistry 274 27529-27535.

Pugazhenthi S, Nesterova A, Sable C, Heidenreich KA, Boxer LM, Heasley LE \& Reusch JE-B 2000 Akt/protein kinase B up-regulates Bcl-2 expression through cAMP-response element-binding protein. Fournal of Biological Chemistry 275 10761-11076. 
Reed JC 1997 Double identity for proteins of the Bcl-2 family. Nature $387773-776$.

Singleton JR, Dixit VM \& Feldman EL 1996 Type I insulin-like growth factor receptor activation regulates apoptotic proteins. Journal of Biological Chemistry 271 31791-31794.

Stefaneanu L, Powell-Braxton L, Won W, Chandrashekar V \& Bartke A 1999 Somatotroph and lactotroph changes in the adenohypophyses of mice with disrupted insulin-like growth factor I gene. Endocrinology 140 3881-3889.

Takahashi S, Oomizu S, Honda J \& Takeuchi S 1997 Insulin-like growth factor I system in the mouse pituitary In Advances in Comparative Endocrinology. Proceedings of the XIII International Congress of Comparative Endocrinology. pp 1123-1126. Eds S Kawashima \& S Kikuyama. Bologna: Monduzzi.

Unger JW \& Lange W 1997 Insulin receptors in the pituitary gland: morphological evidence for influence on opioid peptide-synthesizing cells. Cell Tissue Research 288 471-483.
Vincent AM \& Feldman EL 2002 Control of cell survival by IGF signaling pathways. Growth Hormone and IGF Research 12 193-197.

Yamashita S \& Melmed S 1986 Insulin-like growth factor I action on rat anterior pituitary cells: suppression of growth hormone secretion and messenger ribonucleic acid levels. Endocrinology 118 $176-182$.

Yao R \& Cooper GM 1995 Requirement for phosphatidylinositol-3 kinase in the prevention of apoptosis by nerve growth factor. Science 267 2003-2006.

Zha J, Harada H, Yang E, Jockel J \& Korsmeyer S 1996 Serine phosphorylation of death agonist $\mathrm{BAD}$ in response to survival factor results in binding to $14-13-3$ not Bcl-x $\mathrm{L}_{\mathrm{L}}$. Cell $\mathbf{8 7} 619-628$.

Received in final form 14 February 2004 Accepted 23 February 2004 Made available online as an Accepted Preprint 